\title{
Ricostruire la memoria dello Stato da Mar attraverso un percorso di conoscenza, documentazione e disegno
}

\author{
Sandro Parrinello \\ Silvia La Placa
}

Abstract

Studiare e rendere note le tracce della cultura materiale, riscontrabile nelle architetture militari che testimoniano l'identità dello Stato da Mar veneziano nel Mediterraneo orientale, apre la strada a numerosi processi di connessione tra luoghi e paesi.

L'intento è di ricucire, attraverso il disegno e la rappresentazione, un legame storico che ha qualificato numerose città costiere per secoli governate dalla Serenissima. Mediante l'uso delle tecnologie digitali vengono sperimentati processi e metodi utili alla definizione di banche dati nelle quali raccogliere informazioni circa l'immagine e lo stato di conservazione di tale patrimonio. La costituzione di atlanti descrittivi, utili alla promozione di questi luoghi, e la realizzazione di mostre ed eventi finalizzati ad alimentare un dibattito internazionale su possibili azioni di recupero sono alcuni degli obiettivi del progetto. L'aggiornamento della conoscenza sulle opere d'architettura militare veneziana d'oltremare richiede lo sviluppo di un percorso metodologico volto a qualificare modelli e processi per la diffusione, la comunicazione e la valorizzazione di tale patrimonio. II contributo descrive alcuni risultati della prima esperienza, condotta sul territorio della Dalmazia e del Montenegro, avviata da un gruppo di Università italiane e si concentra maggiormente sull'esperienza relativa alla documentazione delle Bocche di Cattaro, condotta da ricercatori dell'Università di Pavia. Attraverso l'analisi delle architetture fortificate, dei sistemi costruttivi e della storia che ha interessato tali strutture, viene così costruito un archivio digitale dal quale poter comprendere ciò che resta dell'importante opera veneziana per il controllo delle terre d'oltremare.

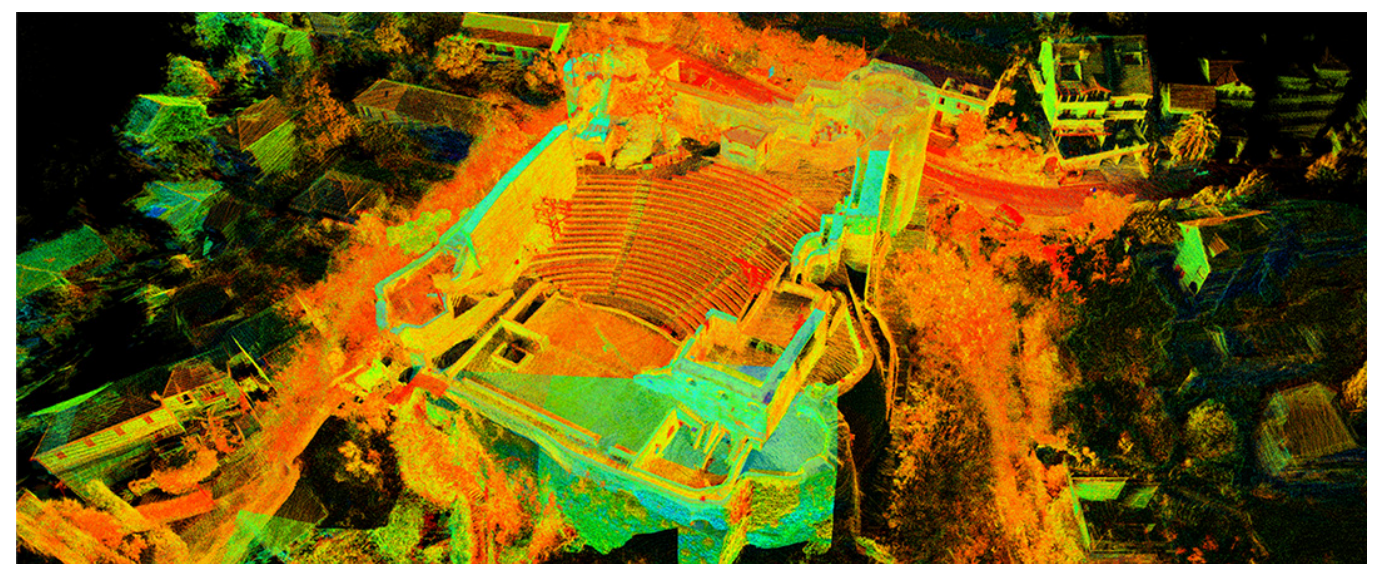




\section{Introduzione}

II contributo intende descrivere un progetto di ricerca, cofinanziato dalla regione Veneto [I], inerente alla documentazione e all'analisi degli storici possedimenti veneziani nel bacino del Mediterraneo orientale [2]. II progetto, concepito su un percorso pluriennale, è volto a costruire un archivio che ponga le basi per una riflessione sull'identità che riveste oggi tale patrimonio e sulle dinamiche che riguardano la sua conservazione e il suo sviluppo. Obiettivo la creazione di un atlante aggiornato delle fortezze in grado di esplicitare e far riscoprire memorie, connessioni e identità culturali, connesse alla Serenissima, che permangono nelle terre d'oltremare. Numerosi palazzi, villaggi e città testimoniano ancora oggi come fosse strutturato lo 'Stato da Mar' veneziano e ciò che resta di queste opere, congiuntamente alla loro storia, racconta quale egemonia fosse imposta nel Mediterraneo. Oggi nell'immagine di queste architetture è possibile definire un importante filo rosso che connette differenti realtà sociali, culturali e commerciali, e che è in grado di esprimere ancora una valenza unificatrice di quella identità mediterranea che emergeva a seguito dei numerosi secoli di influenza veneta. Dialetti, espressioni linguistiche e tradizioni animano un patrimonio immateriale che affianca l'architettura storica dimostrando profonde connessioni, una memoria comune evidenziata in primis dai bassorilievi con il Leone di San Marco sulle porte di accesso e nei monumenti di molte città, tra cui Rodi, Creta, Lefkada, Nicosia, Cattaro e Zara. L'analisi qui presentata si configura come un lungo percorso di conoscenza e valorizzazione in un territorio vasto e dalle differenti caratteristiche geografiche, che si estende dall'Istria alla Dalmazia a Cipro, passando per il Montenegro, Corfü, le Isole lonie, l'Epiro, il Peloponneso, Creta, Rodi e Dodecaneso.

Al fine di pianificare, progettare e ammodernare la difesa della Repubblica dalla minaccia ottomana, durante il Cinquecento numerosi esperti di architettura militare furono inviati nelle coste dell'Adriatico orientale.Tra questi Michele Sanmicheli, maestro del Rinascimento e del Manierismo incaricato dal Senato Veneto di sovrintendere alle fortezze di terra e mare, che proprio attraverso i viaggi in Grecia ebbe modo di rilevare le opere classiche che avrebbero poi caratterizzato il linguaggio stilistico e formale delle sue architetture. In questo senso il rilievo di Porta Terraferma a Zara, ad esempio, costituisce un atto necessario per comprendere a pieno quale linguaggio descriva le note porte della cinta magistrale di Verona.

Fig. I. Attività di documentazione e momenti di lavoro durante la campagna di indagine.
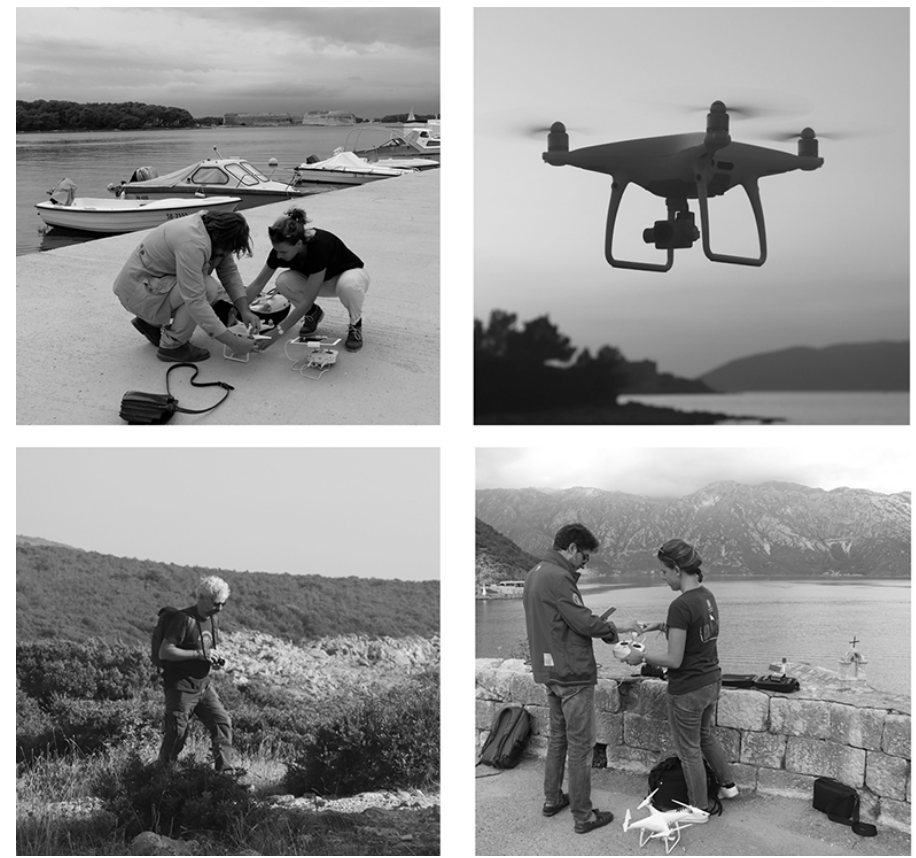

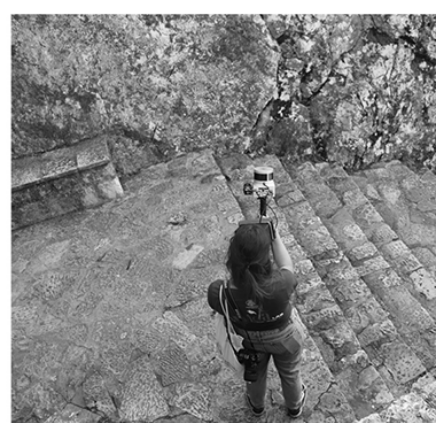


Si delinea una trasmissione di linguaggi, principi architettonici e stilistici propri di un'identità veneta, che da Bergamo fino al Mar Nero trovano ancora una continuità di linguaggio nelle realtà urbane e costiere, in un paesaggio che disegna una rotta culturale [3].

La campagna di indagine condotta dal 24 settembre al 03 ottobre 2019, ha visto i Laboratori DAda-LAB e del laboratorio PLAY [4] impegnati nell'applicazione di differenti strumenti digitali effettuando sperimentazioni che determinassero le più appropriate modalità di ripresa e acquisizione delle misure in relazione ai diversi organismi architettonici oggetto della ricerca (fig. I).
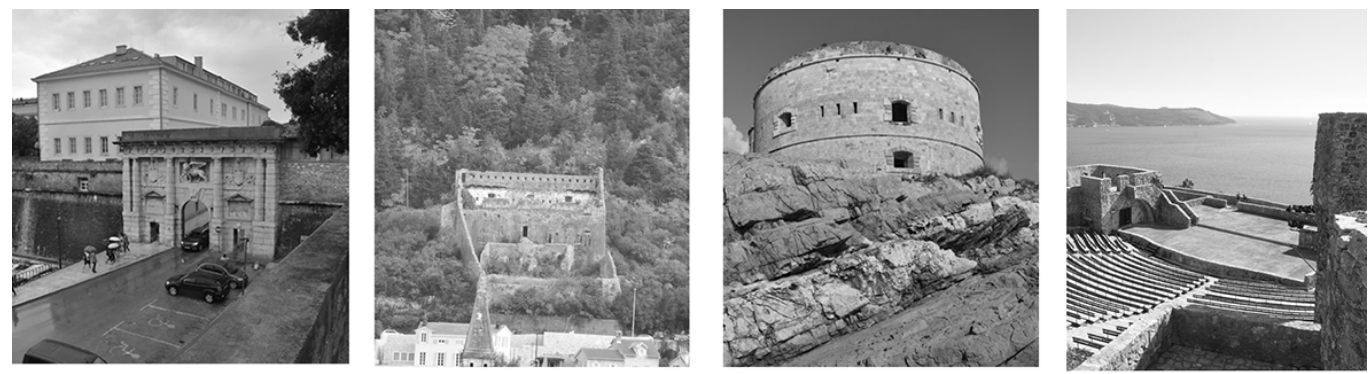

Fig. 2. Da sinistra: Porta di Terraferma di Zara, Forte di Santa Croce a Perasto, Forte di Punta d'Arza, Forte di Kanli Kula, Catena Gospe od Andjela, Forte Mare, Mura del centro storico di Cattaro, vista sulla cittì di Cattaro dalla Fortezza di San Giovann
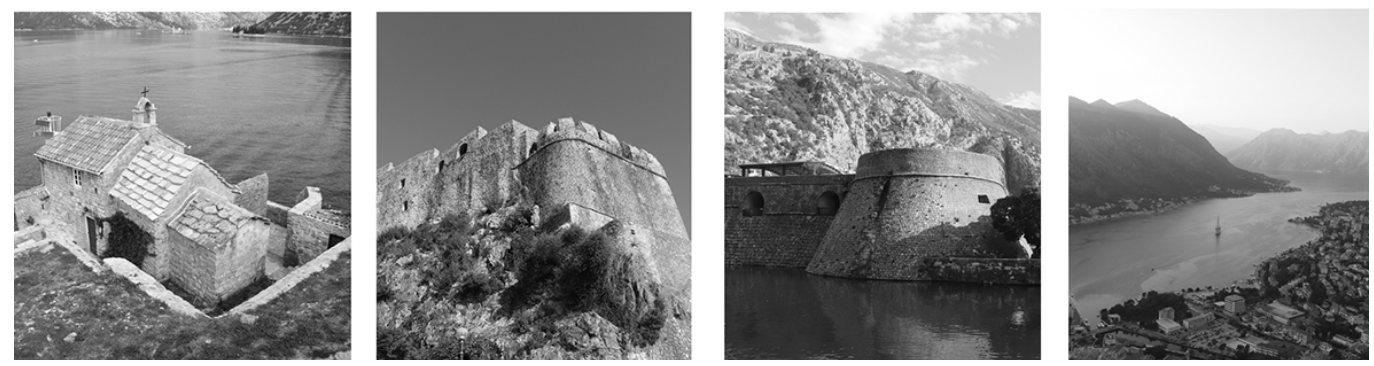

\section{Rilievo speditivo per la produzione di una banca dati affidabile}

Le attività di ricerca sul campo si sono concentrate in tre missioni condotte rispettivamente dall'Università di Pavia, che ha lavorato sulle fortificazioni di Zara e delle Bocche di Cattaro, dall'Università di Firenze, i cui studi si sono concentrati sulle fortezze di Trogir, e dall'Università di Bergamo, che ha documentato le fortificazioni di Antivari. Le campagne di documentazione hanno permesso di costituire una banca dati, un corpus documentale, costituito da nuvole di punti laser scanner, modelli fotogrammetrici, immagini fotografiche e video per ciascuna fortezza o luogo analizzato [5]. I ricercatori dell'Università di Pavia impegnati nel progetto hanno condotto un'indagine di documentazione e mappatura, attraverso l'uso di laser scanner e droni per la Porta di Terraferma di Zara, i forti all'ingresso delle Bocche di Cattaro, i forti di Castelnuovo, il Forte di Santa Croce a Perasto e della catena Gospe od Andjela, oltre allo studio delle mura e del centro storico di Cattaro (fig. 2).

Lo studio e l'analisi del territorio e dei suoi sistemi difensivi ha visto la conduzione di due metodologie di acquisizione per la produzione di una banca dati affidabile: una prima puntuale, che consentisse la lettura delle tessiture murarie e l'analisi delle architetture fortificate, e una seconda ad ampio raggio, che coprisse quei siti per i quali fosse necessario definire un sistema di ordinamento più esteso. Nel centro storico di Cattaro il sistema raccolto dell'aggregato urbano all'interno delle mura si unisce con i percorsi e sentieri che salgono la montagna raggiungendo la fortezza alta definendo un sistema unico che lega città e il paesaggio. II sito UNESCO, che presenta fortezze e strutture militari di notevole pregio, trova spazio tra il mare e la ripida montagna alle sue spalle. La protezione offerta dal golfo e dalla catena montuosa ha da sempre fatto della città un punto strategico di difesa, deputandola 
per l'edificazione di ingenti opere di fortificazione, dalle mura basse al Forte San Giovanni, che sovrasta l'abitato.

Dovendo operare su ingenti dimensioni il progetto ha previsto l'impiego di droni e di laser scanner con tecnologia SLAM, che hanno garantito un notevole vantaggio in termini di tempo. L'acquisizione tramite MLS ha richiesto uno studio preliminare dei percorsi del centro urbano al fine di compiere circuiti concentrici chiusi, pensati in relazione alle diverse quote, in modo da arginare, in fase di trattamento del dato, l'errore di deriva. La strategia di rilevamento ha previsto una suddivisione in tre fasi di acquisizione: una prima per la definizione della cinta muraria acquisita dal perimetro interno ed esterno, una seconda per il centro cittadino, nel quale si è operato per isolati, e una terza per il sistema fortificato che corre sopra il nucleo urbano e culmina con le rovine della fortezza di San Giovanni [6] (fig. 3).

Le operazioni di rilievo fotogrammetrico mediante l'impiego di droni, necessarie per l'integrazione del dato mancante relativo agli ultimi piani e alle coperture degli edifici a completamento del dato acquisito da terra, hanno richiesto l'impostazione di numerosi piani di volo sopra la città, tracciati al fine di ottimizzare gli angoli di ripresa e le diverse quote in funzione dei tipi di drone utilizzati.

L'utilizzo congiunto delle due tecnologie ha garantito la costruzione di una banca dati affidabile per l'intero centro storico di Cattaro e per la sovrastante fortificazione (figg. 4, 6), dalla quale è stato possibile estrarre informazioni morfometriche per lo sviluppo dei modelli (figg. 5, 7).

Fig. 3. Definizione de percorsi per il rilievo con MLS. A sinistra la suddivisione per circuiti concentrici all'interno de centro storico di Cattaro; a destra il percorso per raggiungere Forte San Giovanni.
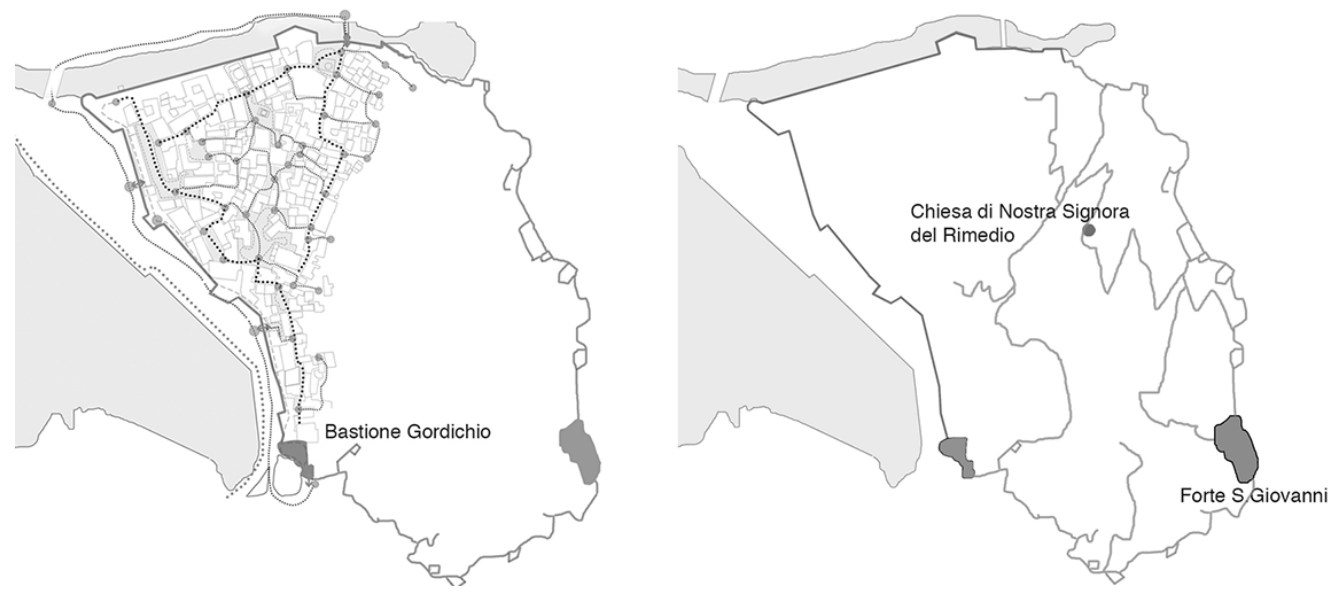

\section{Dalle banche dati ai disegni e modelli delle fortezze}

I dati acquisiti sono stati elaborati attraverso differenti software [7] gestendo così il database di informazioni ottenute e potendo restituire in forma grafica le architetture oggetto della sperimentazione (fig. 8).

La produzione di disegni e modelli a diverse scale, dal dettaglio architettonico al sistema urbano, fornisce informazioni in merito alle caratteristiche costruttive e progettuali tipicamente impiegate dalle maestranze venete.

Le sperimentazioni eseguite integrando i dati della fotogrammetria close range con le nuvole di punti laser scanner, sono servite per elaborare un sistema informativo completo che unisce, alla precisione metrica delle nuvole prodotte dal laser, l'aspetto cromatico e il dato non rilevabile da terra delle nuvole di punti ottenute mediante la fotogrammetria aerea da drone. In particolare, la sperimentazione ha permesso di generare modelli tridimensionali qualitativamente affidabili completi in termini di descrizione di superfici in tutti i volumi architettonici (fig. 9). 
Significativo in questo senso è stato il caso studio di Santa Croce a Perasto: costruita nel 1570 sfruttando la morfologia del pendio, la Fortezza presentava in origine quattro livelli e un ponte sospeso. La rappresentazione grafica (fig. I0), elaborata a partire dalla registrazione della nuvola su Scene [8], permette di leggere ampliamenti, ammodernamenti e modifiche avvenuti fino al XVIII secolo, oltre a restituirne con precisione la condizione attuale: sono andati distrutti tutti gli ambienti del quarto livello, mentre sono visibili i setti murari del terzo e gli ambienti voltati del secondo e del primo, un tempo direttamente collegati con le piazze d'armi.
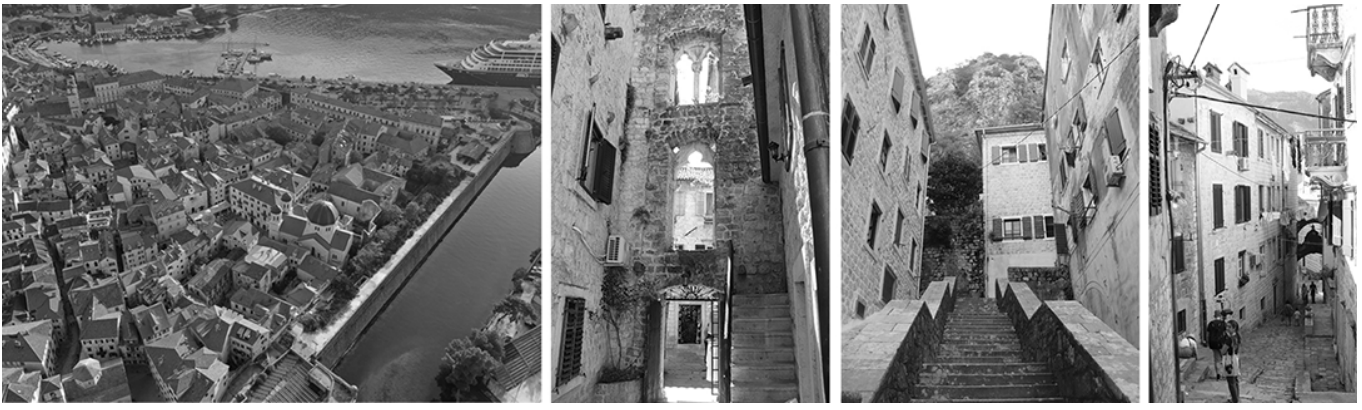

\section{Una mostra per la narrazione del sistema fortificato della Dalmazia e del Montenegro}

I risultati della ricerca sono stati presentati in primo luogo ad una giornata di studi, alla quale hanno partecipato studiosi da tutti gli istituti di ricerca coinvolti nel progetto, a Verona presso il Bastione delle Maddalene, sede del Centro di Documentazione di Verona Città Murata. In occasione di questo incontro, lo scorso ventotto novembre, è stata poi inaugurata una mostra temporanea [9] presso Porta Vescovo. L'allestimento all'interno degli ambienti della porta monumentale veronese ha voluto sottolineare il profondo legame tra la cultura veneta e quella montenegrina, manifesto proprio nelle architetture fortificate. La narrazione, attraverso il disegno e la rappresentazione delle fortezze dello Stato da Mar si è svolta in 26 pannelli affiancati da video e supporti multimediali. A partire dall'ingresso, attraversano i fornici di Porta Vescovo, la mostra accompagna il visitatore in un percorso di disvelamento

Fig. 5. Nuvola di punti

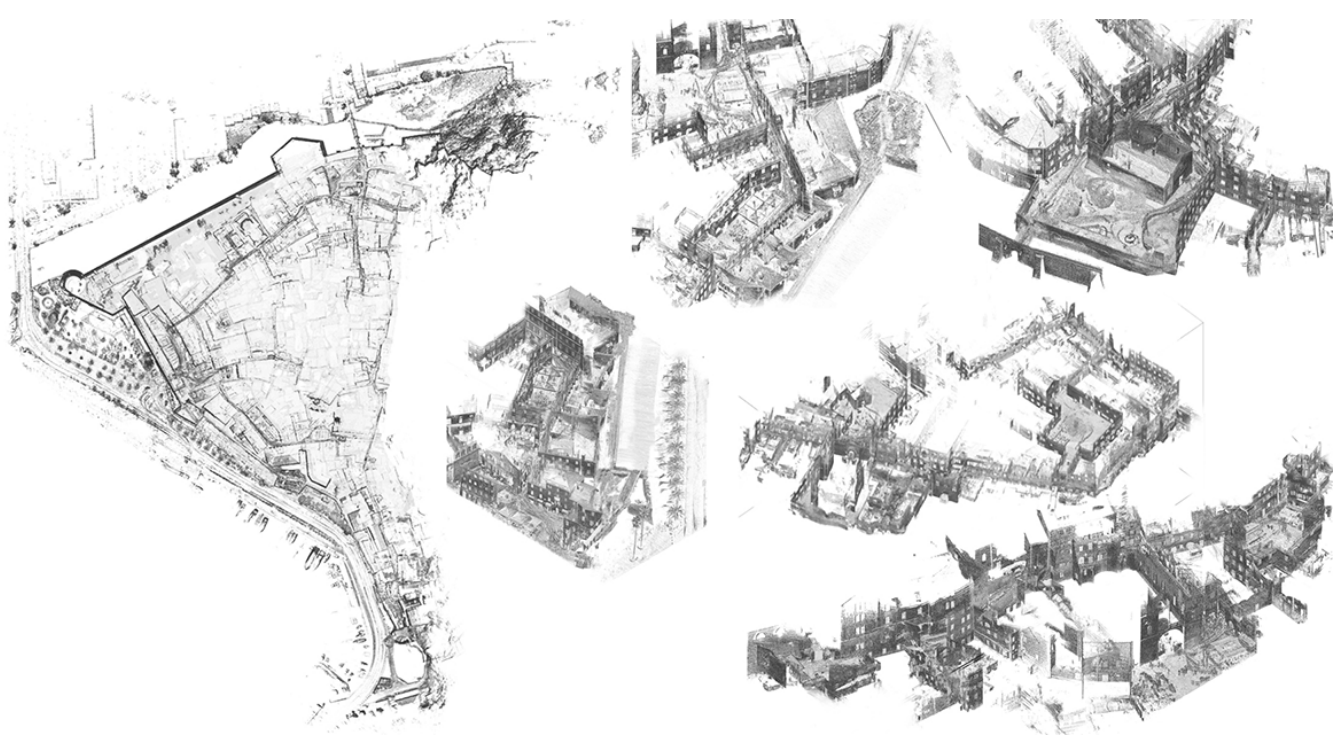



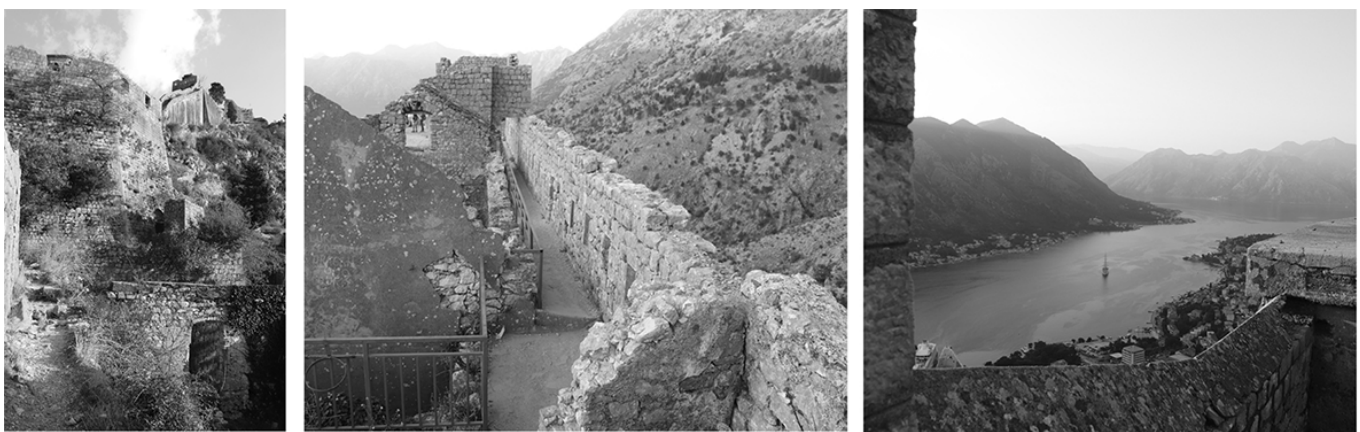

degli ambienti monumentali della porta, parallelamente con la narrazione delle vicende che hanno caratterizzato la ricerca e un racconto che descrive le qualità dei diversi luoghi che contraddistinguono le fortificazioni della Dalmazia e del Montenegro. Come nel viaggio intrapreso dai docenti e dai ricercatori universitari, il visitatore ripercorre idealmente, attraverso un percorso conoscitivo, le tappe che lungo la costa da Trogir, alla baia di Cattaro, arrivano fino città di Stari Bar. Per la narrazione delle opere fortificate è stato scelto un linguaggio grafico essenziale composto da fotografie e disegni supportati da contenuti multimediali installati nelle sale con una video narrazione delle attività di documentazione e la video proiezione dei modelli digitali tridimensionali. La mostra, un atto comunicativo e sociale, ha proposto la definizione di un linguaggio nel quale esplicitare i termini di un legame, descritto attraverso le fortificazioni, che lungo le coste del mar Adriatico promuove l'identità della cultura veneta e veneziana.

La possibilità di rendere noto, attraverso la riproduzione digitale, il patrimonio architettonico da tramandare alle generazioni future, identifica il segno grafico come strumento di conoscenza, comunicazione e promozione dellidentità culturale veneta e veneziana nelle coste del mar Adriatico.

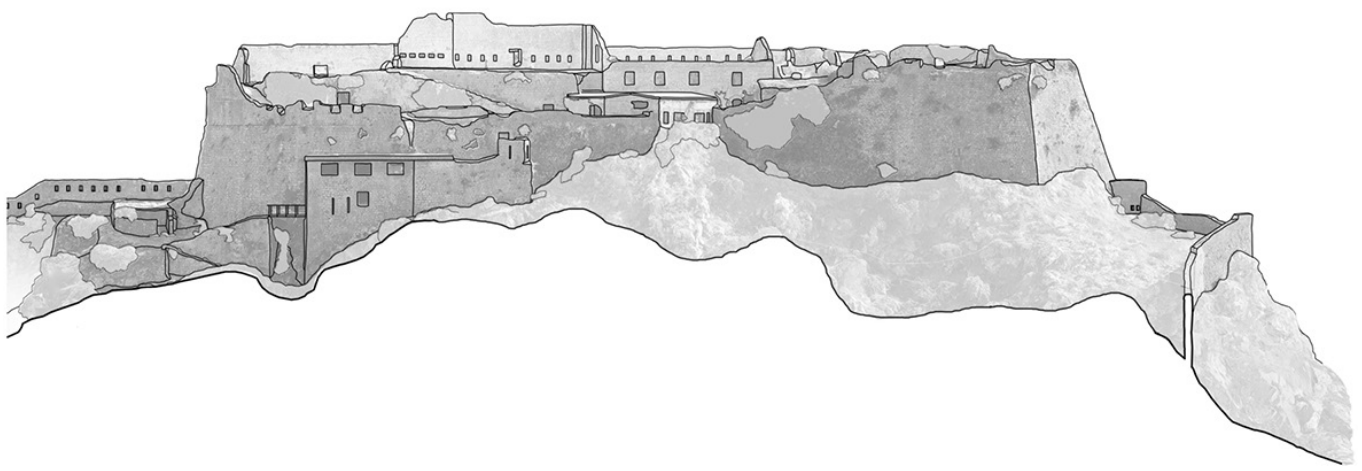

La mostra (fig. I I), pur nel mantenimento di principi scientifici e disciplinari, è stata impostata perché avesse un carattere fortemente divulgativo, che invitasse al dialogo e all'interazione. Lo stesso allestimento, dalle linee essenziali e leggere, sostiene l'esposizione consentendo la contemporanea lettura del retrostante paramento murario della porta cittadina, a voler ancora una volta sottolineare l'importanza connettiva del contenitore.

Lo sviluppo di eventi volti alla divulgazione e alla trasmissione della memoria socioculturale può essere considerato una componente fondamentale per la strutturazione di un'identità comunitaria. Attraverso questo tipo di esperienze il visitatore ha la possibilità di conoscere e ricordare un passato che lo connette alle terre di oltremare, unendo e legando, attraverso il segno grafico di un disegno, di un'immagine e di un modello, tradizioni, storie e culture. 
Fig. 8. Porzione di

cinta muraria della città

Cattaro. Nuvole di punt

a confronto: da sinistra

Laser Mobile Stencil Ka-

arta, Laser Scanner FARO

Drone Dji Phantom 4Pro.
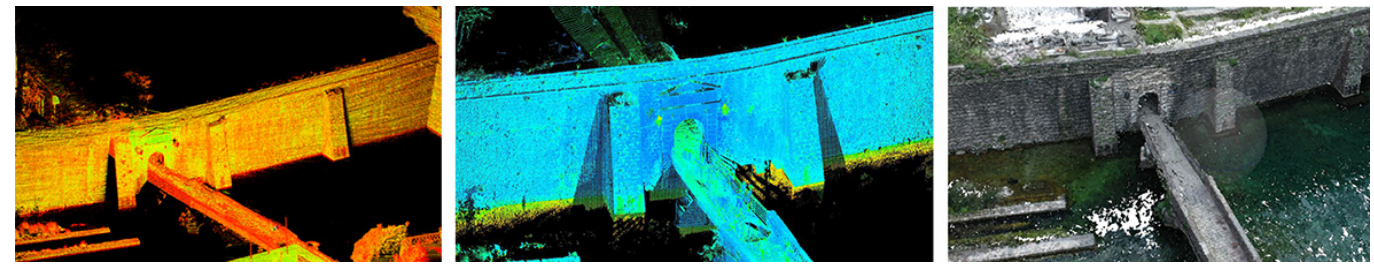

Fig. 9. Fortezza di Kanli

Kula. Porzione del

modello tridimensionale

generato dall'unione dell

nuvola di punti da rilievo

laser scanner mobile

con nuvola di punti da

rilievo fotogrammetrico

da drone.

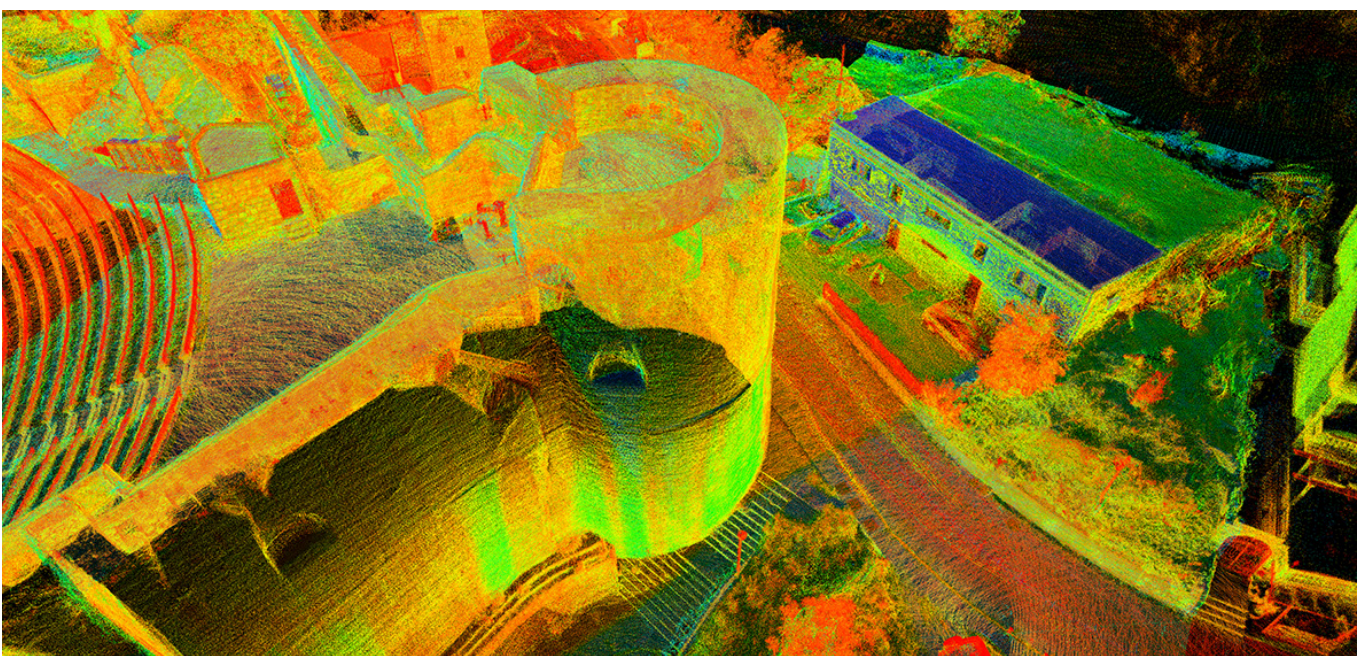

Fig. 10. Fortezza di

Santa Croce, Perasto.

Da sinistra: sezione am-

bientale e assonometria

aborate sul dato della

nuvola di punti registrata

in ambiente CAM2

SCENE.

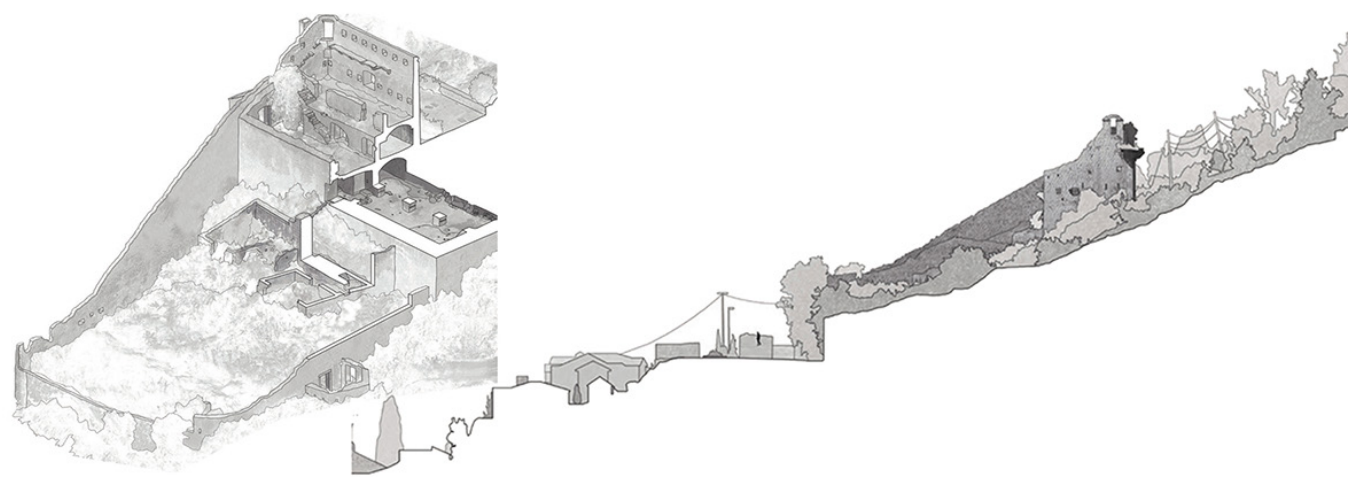


Fig. I I. Immagini della mostra sulle fortezze della Dalmazia e del Montenegro realizzata presso gli ambienti di porta Vescovo a Veron
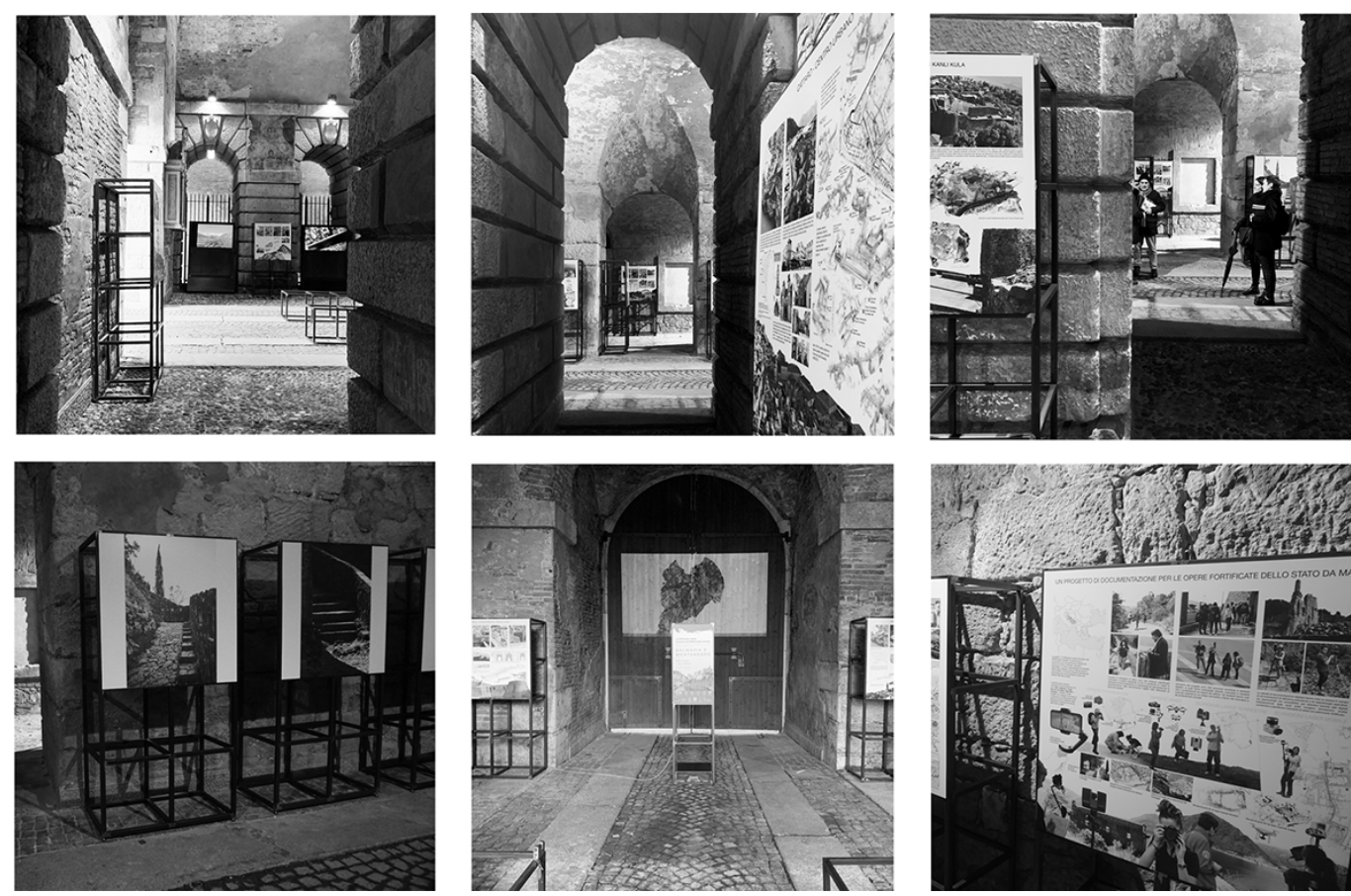

Note

[I] Bando "Iniziative e attivita' culturali per la valorizzazione e la tutela della cultura veneta all'estero - ANNO 20I9" DGR nr. 533 del 30 aprile 2019. Capofila del progetto: Università di Pavia - Dipartimento di Ingegneria Civile e Architettura, laboratorio di Ricerca Sperimentale DAda LAB, Prof. Sandro Parrinello. Partners: Università di Verona - Dipartimento Culture e Civiltà, Prof. Arnaldo Soldani; Università di Bergamo - Scuola di Ingegneria, Prof. Alessio Cardaci; Università di Firenze - DIDA - Dipartimento di Architettura, prof. Stefano Bertocci; Università del Montenegro - Facoltà di Architettura, prof. llia Lalosevic; Comune di Verona.

[2] Si devono a Sandro Parrinello "Introduzione" e "Una mostra per la narrazione del sistema fortificato della Dalmazia e del Montenegro" e a Silvia La Placa i paragrafi "Il Rilievo speditivo per la produzione di una banca dati affidabile" e "Dalle banche dati ai disegni e modelli delle fortezze". Tutte le immagini del contributo sono di proprietà degli autori.

[3] II sito seriale transnazionale "Le opere di difesa veneziane tra il XVI e XVII secolo: Stato da Terra - Stato da Mar Occidentale" è costituito da sei strutture dislocate in Italia, Croazia e Montenegro e si estende per oltre $1000 \mathrm{~km}$ tra la Lombardia e la costa adriatica orientale. Queste ampie e innovative reti difensive stabilite dalla Repubblica di Venezia hanno un eccezionale valore storico, architettonico e tecnologico e contribuiscono alla configurazione del paesaggio, rafforzando la qualità del campo visivo delle sei strutture, nonché le strutture urbane e difensive risalenti a periodi storici precedenti (medievali) e più recenti (come le modifiche e le aggiunte del periodo napoleonico e ottomano). Fanno parte del sito Unesco le opere di difesa presenti a Bergamo, Palmanova e Peschiera del Garda per l'Italia, Zara e Sebenico per la Croazia, Cattaro per il Montenegro. <http:// www.unesco.it/it/PatrimonioMondiale/Detail/480>. Le attività proposte nel progetto hanno tra gli obiettivi quello di fornire al sito UNESCO una più completa visione delle opere veneziane disseminate nel Mediterraneo.

[4] La campagna di rilievo, coordinata dal prof. Sandro Parrinello, è stata condotta da dott.ssa Francesca Picchio, PhD Student Anna Dell'Amico, PhD Student Silvia La Placa, Msc. Stud. Chiara Malusardi, Studenti Dante Certomà e Alberto Pettineo. Parallelamente è stata realizzata una campagna fotografica tesa a definire gli aspetti più peculiari e rappresentativi del patrimonio, curata dal prof. Marco Morandotti.

[5] Modelli fotogrammetrici ottenuti mediante campagne di acquisizione Close Range condotte sia da terra con macchine fotografiche reflex settate manualmente che attraverso droni Dji. Acquisizioni laser scanner effettuate con due strumentazioni: Laser Scanner FARO CAM2 FOCUS SI50 e Laser Mobile Stencil Kaarta. Sistemi di ripresa video mediante videocamere e camere di ripresa fotografica a $360^{\circ}$.

[6] L'attività sul campo ha avuto durata di 16 ore, 237 scansioni, per coprire l'intero centro urbano e di 2 ore, 64 scansioni, per il raggiungere e rilevare il forte San Giovanni.

[7] Per le nuvole di punti acquisite con tecnologia TLS la registrazione è avvenuta mediante software CAM2 SCENE, mentre il dato da sistema MLS è stato gestito attraverso i software Cloud Compare e Cyclone.

[8] II rilievo laser di Santa Croce, realizzato per tutto l'esterno e per tutti gli ambienti interni accessibili, è stato effettuato con strumentazione Laser Scanner FARO CAM2 FOCUS SI50 settato per la restituzione del colore. La registrazione è stata effettuata su software SCENE, riportando un errore inferiore ad $1 \mathrm{~cm}$.

[9] Al termine del convegno, tenutosi il giorno 21 novembre 2019, è stata inaugurata la mostra, che è rimasta aperta fino al 30 novembre 2019. Per ulteriori informazioni <http://dadalab.unipv.it/le-fortificazioni-venete-nel-bacino-del-mediterraneoorientale-porta-vescovo-verona-21-30-||-20|9/>. 


\section{Riferimenti bibliografici}

Arbel Benjamin (1996). Colonie d'oltremare. In Menniti Ippolito Antonio, Benzoni Gino (a cura di). Storia di Venezia. Dalle origini alla caduta della Serenissima, V, II Rinascimento. Roma: Istituto della Enciclopedia italiana, vol. 5, pp. 947-985.

Arbel Benjamin (2013). Venice's maritime Empire in the early modern period. In Eric R. Dursteler (a cura di). A Companion to venetian history, 1400- 1 797. Leiden: Brill's Companions to European History, pp. I25-254.

Gherado Ortalli, Oliver Jens Schmitt (a cura di). (2009). Balcani Occidentali, Adriatico e Venezia fra XIII e XVIII secolo/ Der Westliche Balkan, Der Adriaraum Und Venedig $13^{\text {th }}-18^{\text {th }}$. Jahrhundert. Venezia-Vienna: Austrian Academy of Sciences.

Hocquet Jean Claude (1989). Fiscalité et pouvoir colonial.Venise et le sel Dalmate aux XV et XVI siècles. In Balard Michel (ed.). État et colonisation au Moyen Âge. Lyon: La Manufacture, pp. 277-3I6.

Krekić Bariša (1995). Venezia e l'Adriatico. In Arnaldi Girolamo, Cracco Giorgio, Tenenti Alberto (a cura di). Storia di Venezia. Dalle origini alla caduta della Serenissima, III, La formazione dello stato patrizio. Roma: Istituto della Enciclopedia italiana, vol. 3 , pp. 5 | -85 .

Paladini Filippo Maria (2002). Un caos che spaventa. Poteri, territori e religioni di frontiera nella Dalmazia della tarda età veneta. Venezia: Marsilio Editore.

Praga Giuseppe (1981). Storia di Dalmazia. Milano: Dall'Oglio.

Parrinello Sandro, Picchio Francesca (a cura di). (2019). Dalmazia e Montenegro. Le fortificazioni Venete nel Bacino del Mediterraneo Orientale. Procedure per la conoscenza e la Documentazione Digitale del Patrimonio Storico Fortificato. Pavia: Pavia University Press.

\section{Autori}

Sandro Parrinello, Università degli Studi di Pavia, sandro.parrinello@unipv.it

Silvia La Placa, Università degli Studi di Pavia, silvia.laplaca@unipv.it

Per citare questo capitolo: Parrinello Sandro, La Placa Silvia (2020). Ricostruire la memoria dello Stato da Mar attraverso un percorso di conoscenza, documentazione e disegno/Rebuilding the Memory of the State da Mar through a path of knowledge, documentation and drawing. In Arena A., Arena M., Brandolino R.G., Colistra D., Ginex G., Mediati D., Nucifora S., Raffa P. (a cura di). Connettere. Un disegno per annodare e tessere. Atti del $42^{\circ}$ Convegno Internazionale dei Docenti delle Discipline della Rappresentazione/Connecting. Drawing for weaving relationships. Proceedings of the 42th International Conference of Representation Disciplines Teachers. Milano: FrancoAngeli, pp. 2533-2550. 


\title{
Rebuilding the Memory of the State da Mar through a Path of Knowledge, Documentation and Drawing
}

\author{
Sandro Parrinello \\ Silvia La Placa
}

Abstract

Studying and making known the traces of material culture, found in military architecture that testify to the identity of the state from the Venetian Sea in the eastern Mediterranean, opens the way for numerous processes of connection between places and countries.

The intent is to mend, through design and representation, a historical link that has qualified numerous coastal cities for centuries governed by the Serenissima Republic. Through the use of digital technologies, are tested processes and methods useful for defining databases in which to collect information about the image and the state of conservation of this heritage. Some of the objectives of the project are the creation of descriptive atlases, useful for promoting these places, and the creation of exhibitions and events, aimed at fueling an international debate on possible recovery actions. Updating knowledge on works of overseas Venetian military architecture requires the development of a methodological path aimed at qualifying models and processes for the dissemination, communication and enhancement of this heritage.

The contribution describes some results of the first experience, conducted on the territory of Dalmatia and Montenegro, started by a group of Italian universities and focuses more on the experience related to the documentation of the Bocche di Cattaro, conducted by researchers from the University of Pavia. Through the analysis of the fortified architectures, the construction systems and the history that affected these structures, a digital archive is thus built from which to understand what remains of the important Venetian work for the control of overseas lands.

Keywords

3D Fast Survey, 3D models and databases, Fortified Architecture, Stato da Mar, Dalmazia-Montenegro.

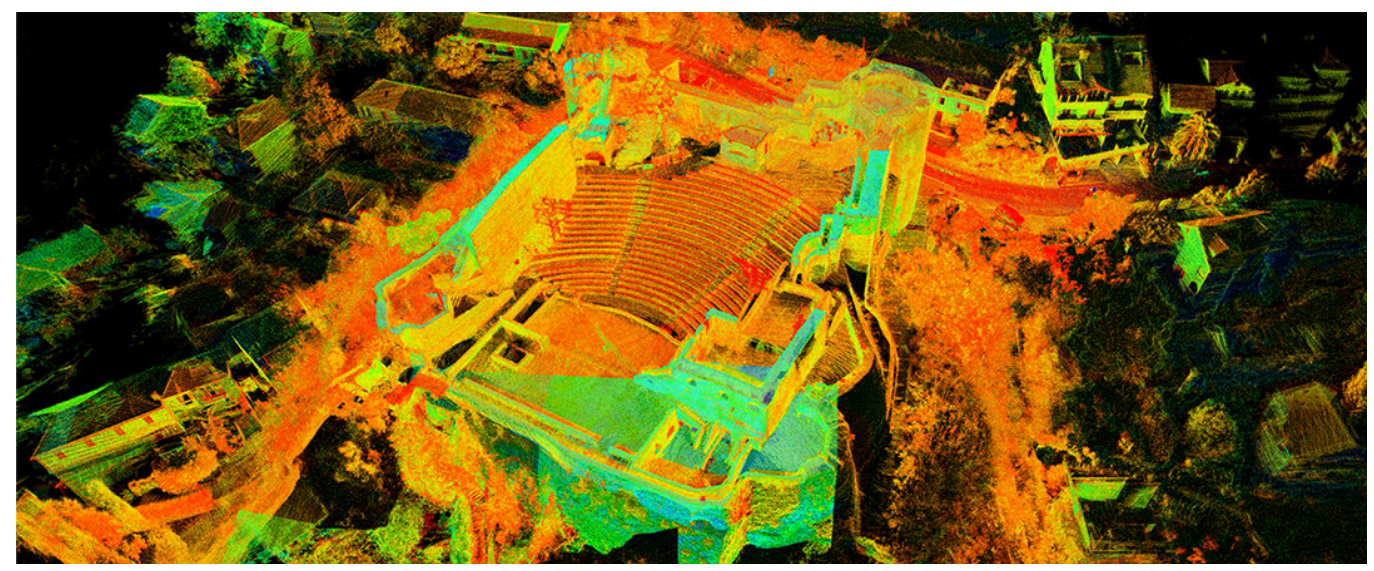




\section{Introduction}

The contribution aims to describe a research project, co-financed by the Veneto region [I], relating to the documentation and analysis of the historic Venetian possessions in the eastern Mediterranean basin [2]. The project, conceived on a multi-year path, is aimed at building an archive that lays the foundations for a reflection on the identity that today covers this heritage and on the dynamics that affect its conservation and development. The aim is to create an updated atlas of the fortresses capable of making explicit and rediscovering memories, connections and cultural identities, connected to the Serenissima, which remain in overseas lands. Numerous palaces, villages and cities still testify today how the Venetian 'Stato da Mar' was structured and what remains of these works, together with their history, tells the imposed hegemony in the Mediterranean. Today in the image of these architectures it is possible to define an important red thread that connects different social, cultural and commercial realities. This thread is still able to express a unifying value of the Mediterranean identity that emerged following the many centuries of Venetian influence. Dialects, linguistic expressions and traditions animate an intangible heritage that supports historical architecture. Deep connections and a common memory are highlighted primarily by the bas-reliefs with the Lion of San Marco on the access gates and in the monuments of many cities, including Rhodes, Crete, Lefkada, Nicosia, Kotor and Zadar. The analysis here presented is configured as a long journey of knowledge and enhancement in a vast territory with different geographical characteristics, which extends from Istria to Dalmatia to Cyprus, passing through Montenegro, Corfu, the Ionian Islands, Epirus, the Peloponnese, Crete, Rhodes and Dodecanese.

To plan, design and modernize the defense of the Republic from the Ottoman threat, numerous military architecture experts were sent to the eastern Adriatic coast during the sixteenth century. Among these Michele Sanmicheli, master of the Renaissance and Mannerism commissioned by the Venetian Senate to supervise the fortresses of land and sea, which through his travels in Greece had the opportunity to detect the classic works that would later characterize the stylistic and formal language of its architecture. In this sense, the relief of Porta Terraferma in Zara, for example, is a necessary act to fully understand which language describes the well-known doors of the magistral walls of Verona. A transmission

Fig. I. Documentation activities and work moments during the survey campaign.
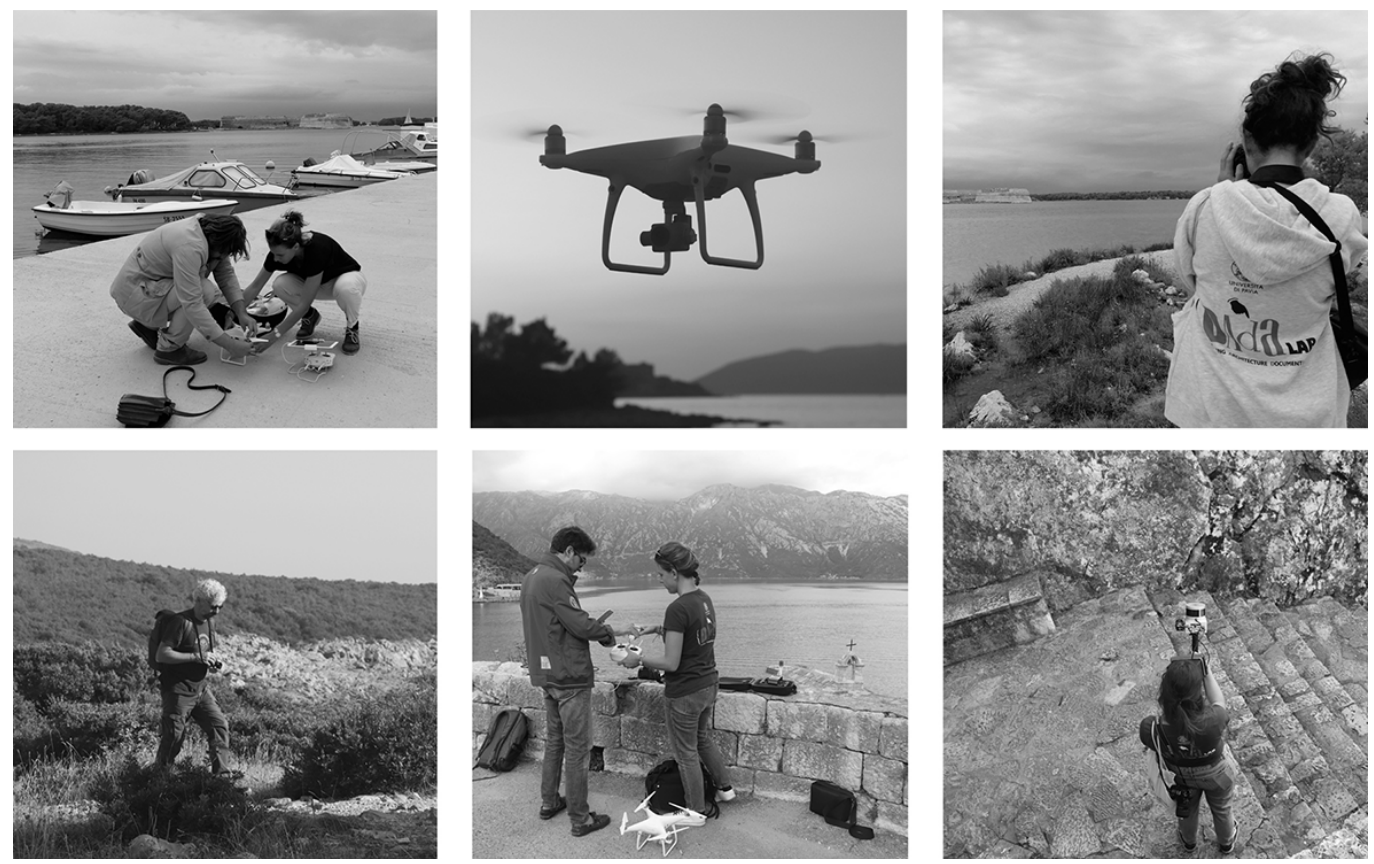
of languages, architectural and stylistic principles typical of a Venetian identity, which from Bergamo to the Black Sea still find a continuity of language in urban and coastal realities, in a landscape that draws a cultural route [3]. The investigation campaign, conducted from 24 September to 03 October 2019, saw the DAda-LAB and the PLAY laboratory [4] engaged in the application of different digital instruments carrying out experiments that determined the most appropriate methods of recovery and acquisition of the measures concerning the various architectural bodies being researched (fig. I).
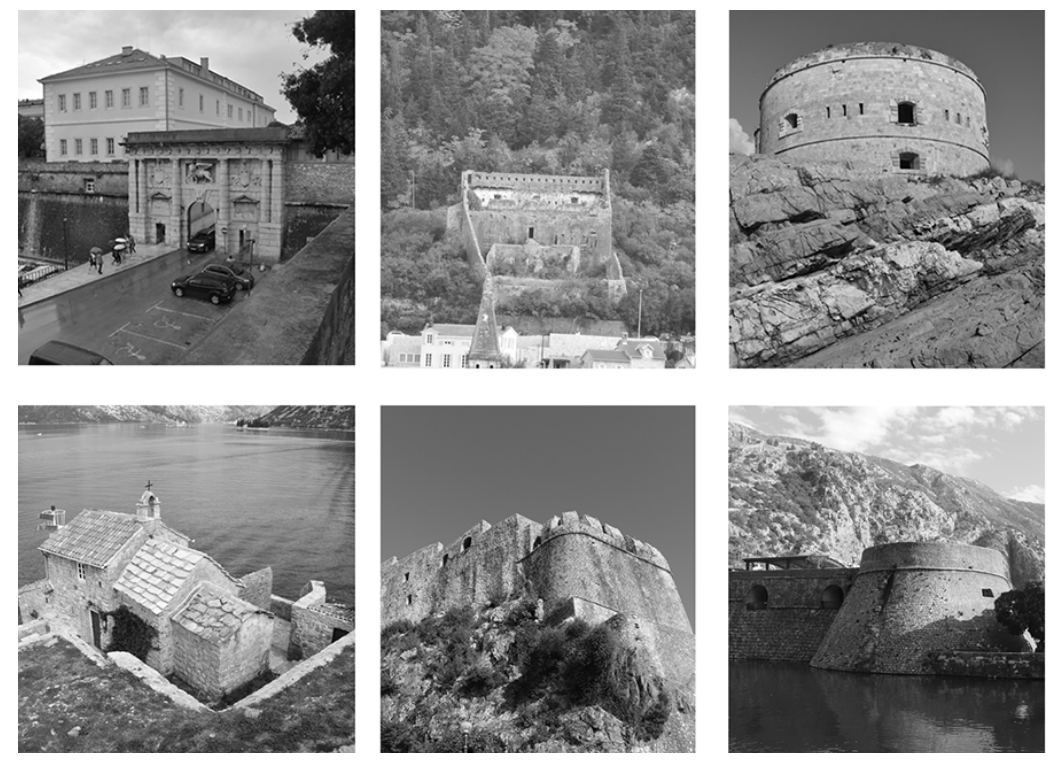
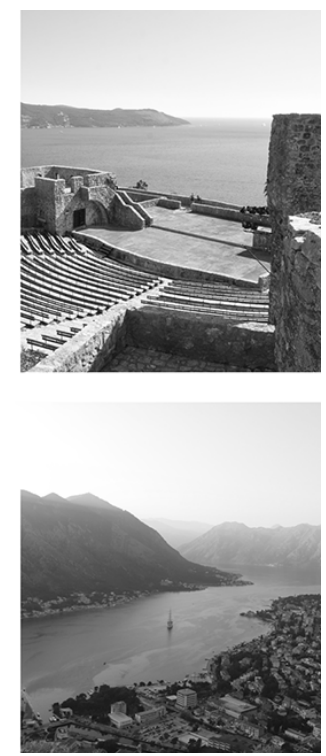

Fig. 2. Kanli Kula, Catena Gospe od Andjela, historic center of Kotor, view of the city of Koto Giovanni.

\section{Fast survey for the production of a reliable database}

Field research activities focused on three missions conducted respectively by the University of Pavia, which worked on the fortifications of Zadar and the Bocche di Cattaro, by the University of Florence, whose studies concentrated on the fortresses of Trogir, and from the University of Bergamo, which documented the fortifications of Bar.The documentation campaigns made it possible to set up a database, a document body, consisting of clouds of laser scanner points, photogrammetric models, photographic and video images for each fortress or place analyzed [5].The researchers of the University of Pavia engaged in the project conducted a documentation and mapping investigation, through the use of laser scanners and drones for the Zadar mainland gate, the forts at the entrance to the Strait of Kotor, the forts of Castelnuovo, the Fort of Santa Croce in Perasto and the Gospe od Andjela chain, as well as the study of the walls and the historic center of Kotor (fig. 2).

The study and analysis of the territory and its defensive systems saw the conduct of two acquisition methodologies for the production of a reliable database: a first punctual one, which allowed the reading of the wall textures and the analysis of the fortified architectures, and a second wide-ranging one, covering those sites for which it was necessary to define a more extensive sorting system. In the historic center of Kotor, the collected system of the urban aggregate within the walls joins the paths that climb the mountain reaching the high fortress, defining a unique system that links the city and the landscape. The UNESCO site, which has fortresses and military structures of considerable value, is located between the sea and the steep mountain behind it. The protection offered by the gulf and the mountain range has always made the city a strategic defence point, delegating it for the construction 
of huge fortification works, from the low walls to Fort San Giovanni, which overlooks the town. Having to operate on large dimensions, the project involved the use of drones and laser scanners with SLAM technology, which guaranteed a significant time advantage. The acquisition through MLS required a preliminary study of the paths of the urban center to make closed concentric circuits, designed to the different altitudes, to stem, during the data processing phase, the drift error. The survey strategy envisaged a subdivision into three acquisition phases: a first for the definition of the walls, acquired from the internal and external perimeter, a second for the city center, in which it was operated in blocks, and a third for the system fortified that runs above the urban core and culminates with the ruins of the fortress of San Giovanni [6] (fig. 3).

The photogrammetric survey operations through the use of drones, necessary for the integration of the missing data relating to the top floors and the roofs of the buildings to complete the data acquired from the ground, required the setting of numerous flight plans over the city, traced to optimize the shooting angles and the different altitudes according to the types of drone used.

The joint use of the two technologies ensured the construction of a reliable database for the entire historic center of Kotor and for the overlying fortification (figs. 4, 6), from which it was possible to extract morphometric information for the development of the models (figs. 5, 7).
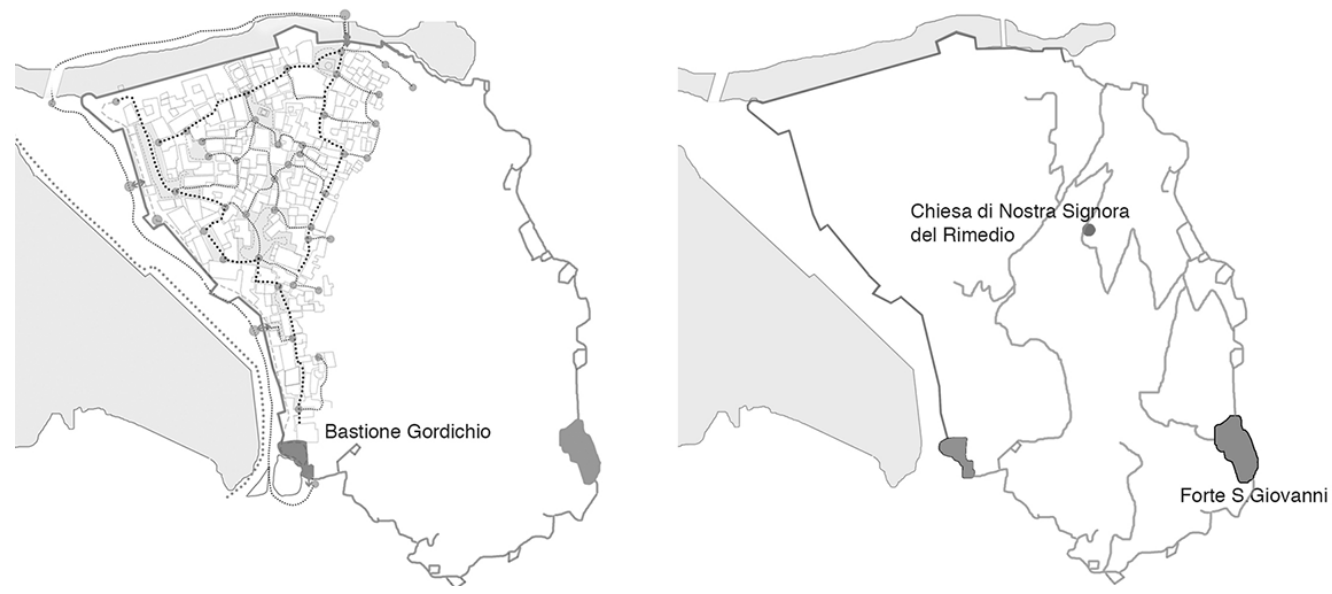

\section{From databases to drawings and models of fortresses}

The acquired data were processed through different software [7] thus managing the database of information obtained and being able to return the architectures subject to experimentation in graphic form (fig. 8).

The production of designs and models at different scales, from the architectural detail to the urban system, provides information on the construction and design characteristics typically used by Venetian workers.

The experiments carried out by integrating the close-range photogrammetry data with the clouds of laser scanner points were used to develop a complete information system that combines the metric precision of the clouds produced by the laser with the chromatic aspect and the undetectable data from the ground of the point clouds obtained by drone aerial photogrammetry. In particular, experimentation has enabled the generation of qualitatively reliable three-dimensional models complete in terms of the description of surfaces in all architectural volumes (fig. 9). 

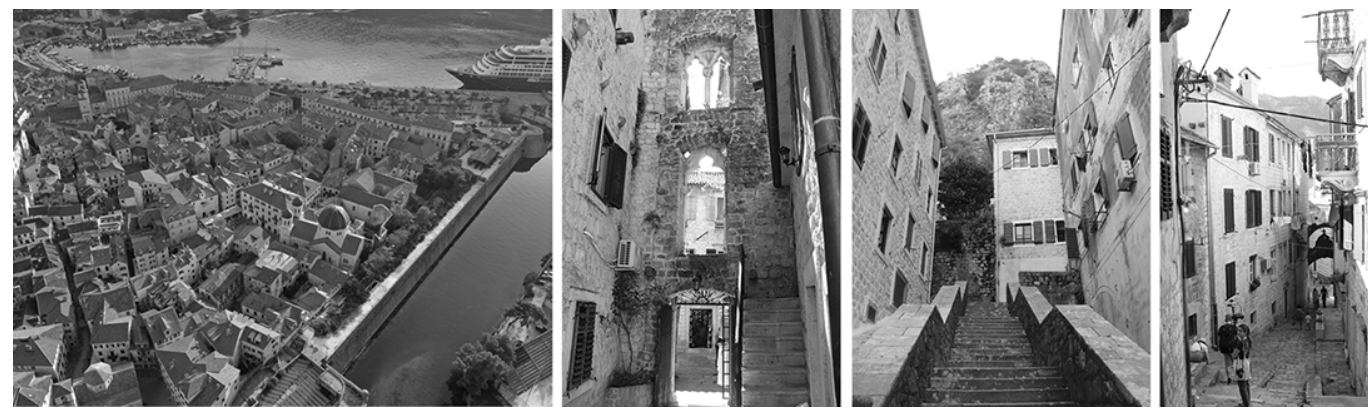

\section{An exhibition for the narration of the fortified system of Dalmatia and Montenegro}

The results of the research were presented first of all at a study day, in which scholars from all the research institutes involved in the project participated, in Verona at the Bastione delle Maddalene, home of the Verona City Center. On the occasion of this meeting, on the twenty-eighth of November, a temporary exhibition [9] was then inaugurated at Porta Vescovo. The installation inside the rooms of the Veronese monumental door wanted to underline the profound link between Venetian and Montenegrin culture, manifested precisely in the fortified architecture. The narration, through the design and representation of the fortresses of the "State da Mar" took place in 26 panels flanked by videos and multimedia supports. Starting from the entrance, through the arches of Porta Vescovo, the exhibition accompanies the visitor on a journey of unveiling the monumental environments of the door, in parallel

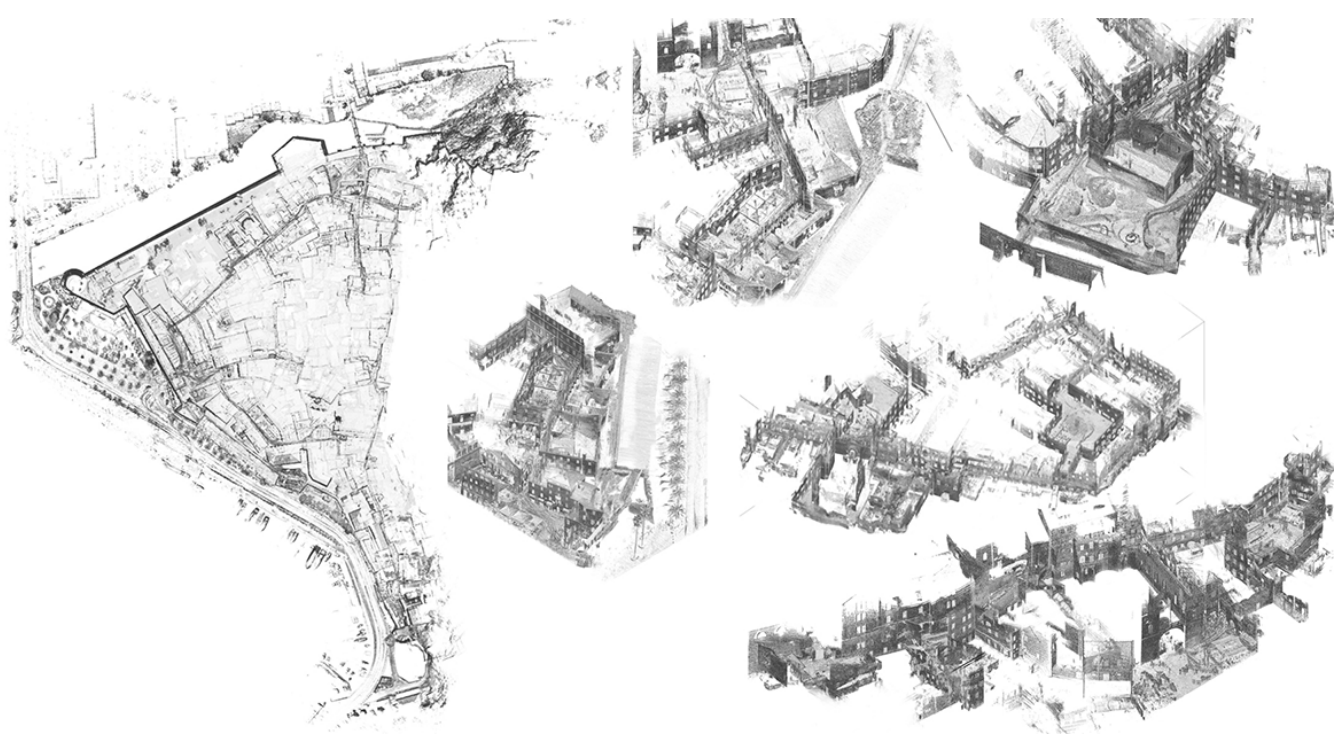



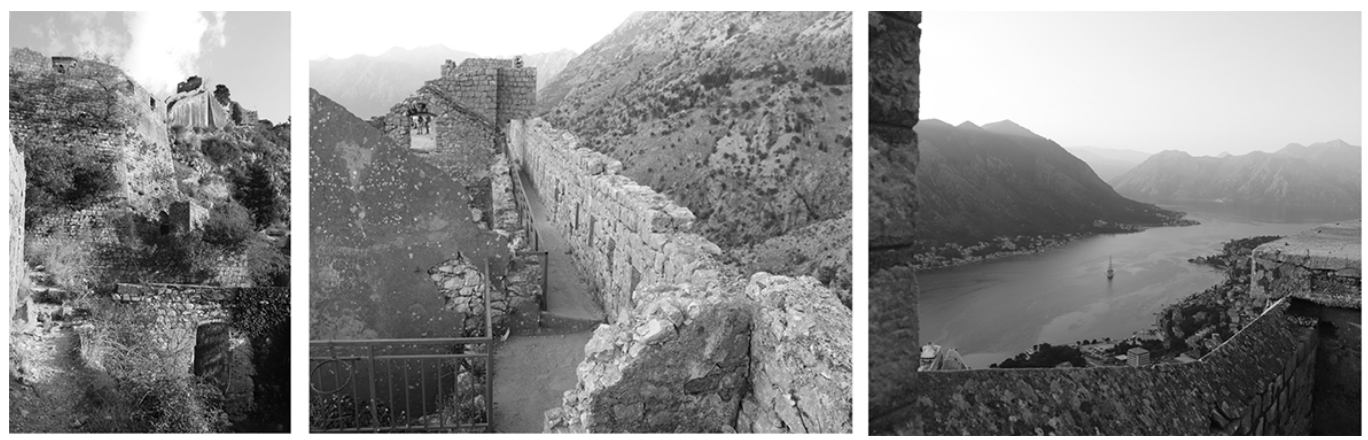

with the narration of the events that characterized the research and a story that describes the qualities of the different places. which distinguish the fortifications of Dalmatia and Montenegro. As in the journey undertaken by professors and university researchers, the visitor ideally retraces, through a cognitive journey, the stages that along the coast from Trogir, to the Bay of Kotor, reach the city of Stari Bar. For the narration of the fortified works, it was chosen an essential graphic language composed of photographs and drawings supported by multimedia content installed in the rooms with a video narration of the documentation activities and the video projection of the three-dimensional digital models. The exhibition, a communicative and social act, proposed the definition of a language in which to clarify the terms of a bond, described through the fortifications, which along the coasts of the Adriatic Sea promotes the identity of the Venetian and Venetian culture. The possibility of making known, through digital reproduction, the architectural heritage to be handed down to future generations, identifies the graphic sign as a tool for knowledge, communication and promotion of the Venetian and Venetian cultural identity on the coasts of the Adriatic Sea.

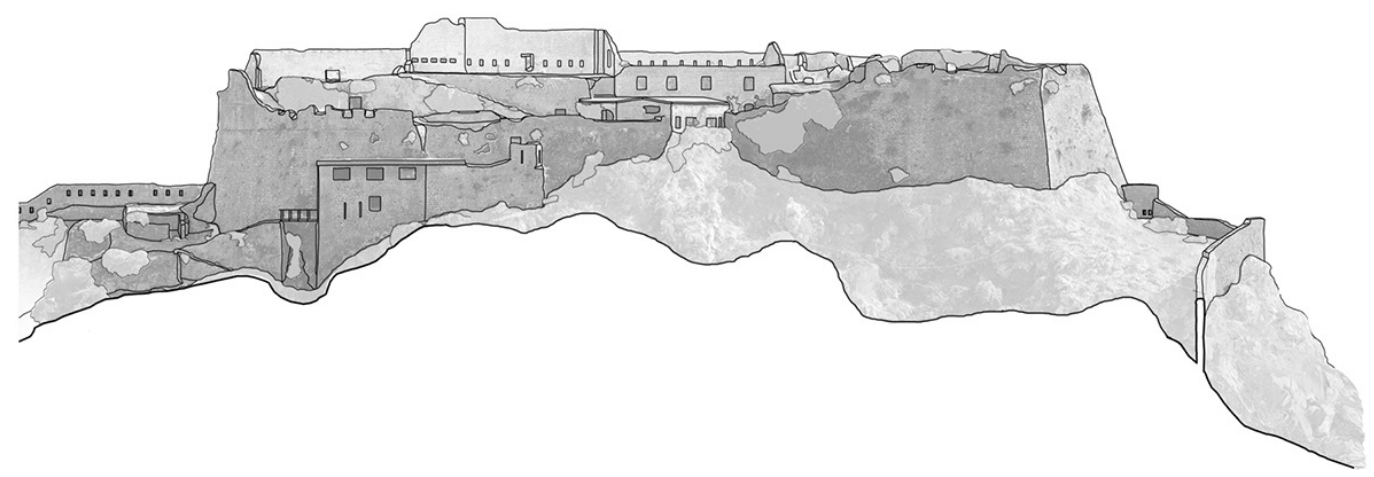

The exhibition (fig. II), while maintaining scientific and disciplinary principles, was set up to have a highly popular character, which would invite dialogue and interaction. The same setup, with essential and light lines, supports the display allowing the simultaneous reading of the back wall of the city door, once again wanting to underline the connective importance of the container. The development of events aimed at the dissemination and transmission of socio-cultural memory can be considered a fundamental component for the structuring of a community identity. Through this type of experience, the visitor has the opportunity to know and remember a past that connects it to the lands of overseas, uniting and binding, through the graphic sign of a drawing, an image and a model, traditions, stories and cultures. 
Fig. 8. Kanli Kula

fortress. Portion of the

three-dimensional mode

generated by the union

of the point cloud from

mobile laser scanner

survey with point cloud

from photogrammetric

survey from drone.
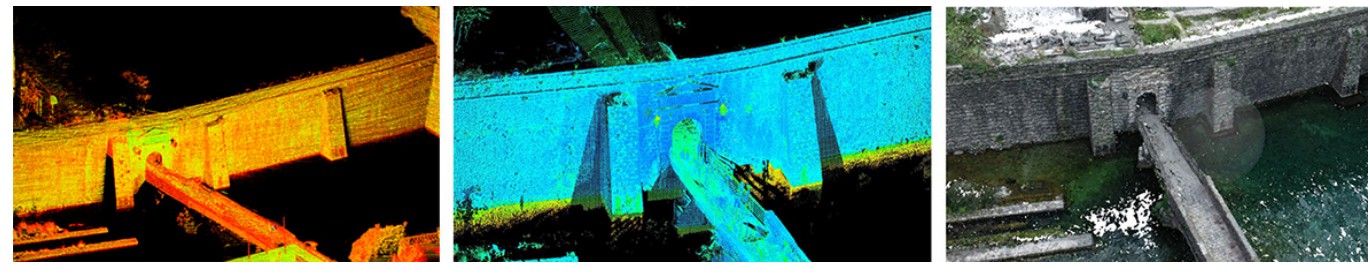

Fig. 9. Portion of the city wall of Kotor. Point clouds compared: from the left Mobile Laser Stencil Ka-

arta, Laser Scanner FARO Drone Dji Phantom 4Pro.

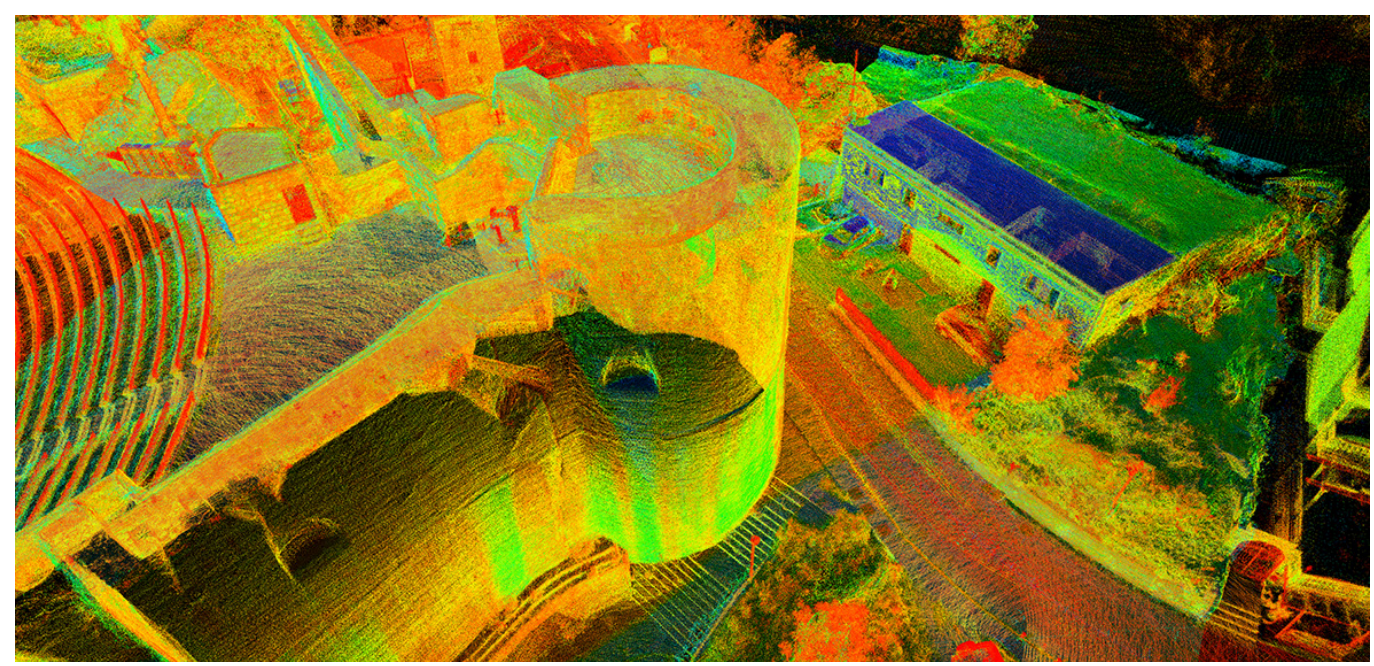

Fig. 10. Fortress of Santa Croce, Perasto. F left: environmental section and axonometry elaborated on the point cloud data recorded

in the CAM2 SCENE

environment.

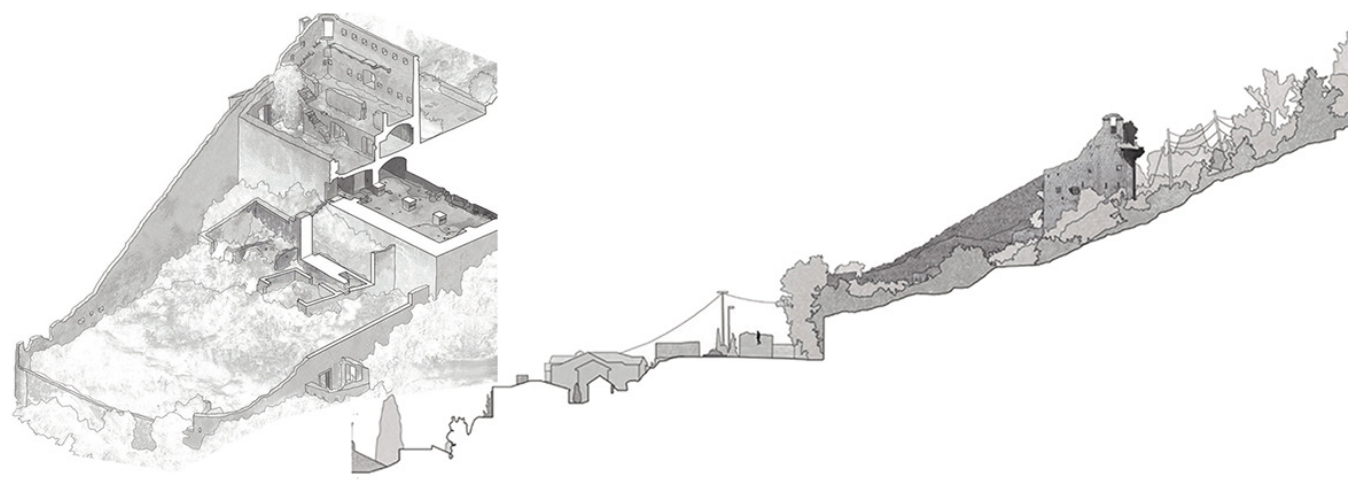


Fig. I I. Images of the exhibition on the fortresses of Dalmatia and Montenegro realized in the environments of Porta Vescovo in Verona.
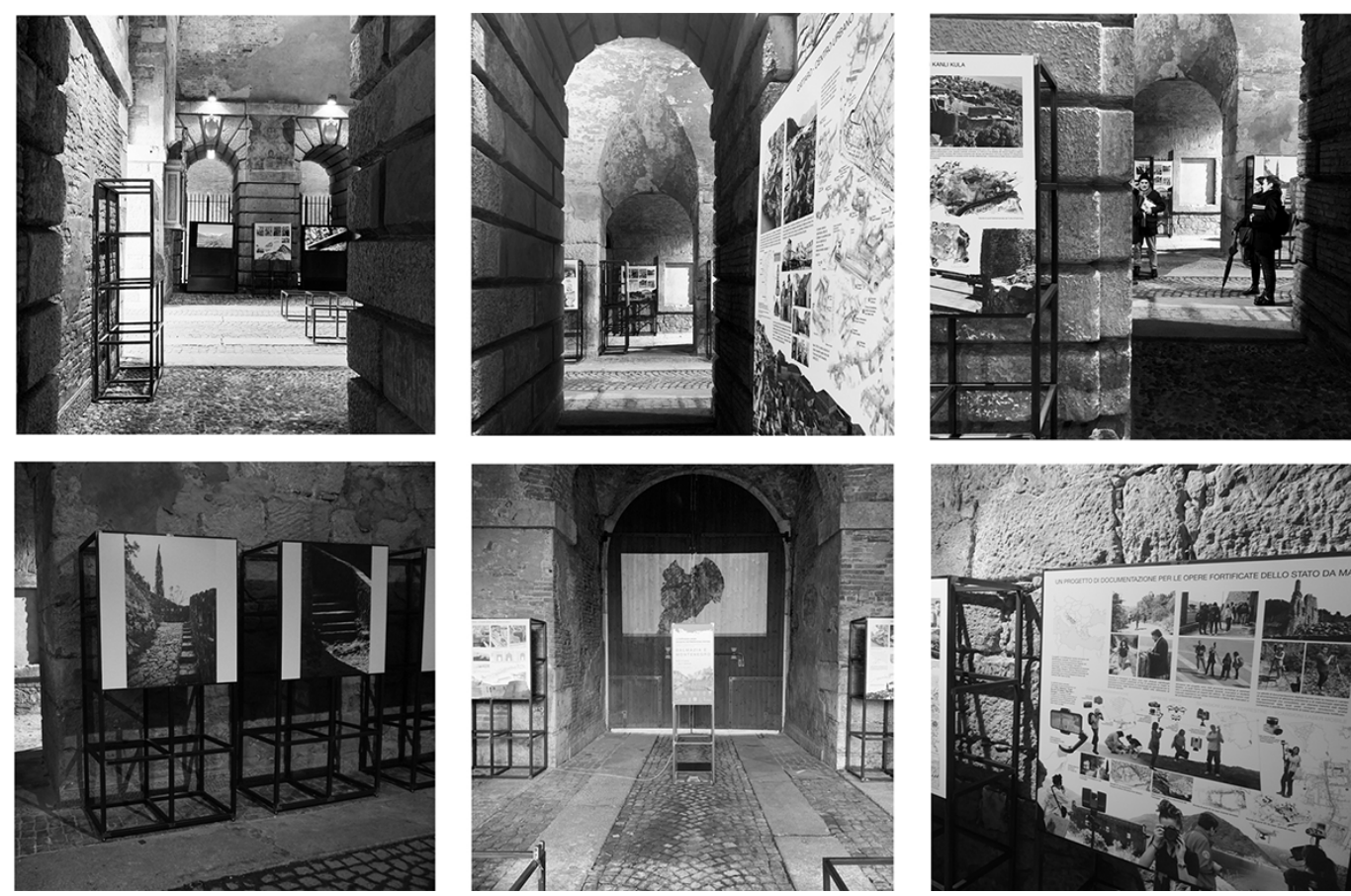

\section{Note}

[I] Call "Cultural initiatives and activities for the enhancement and protection of Venetian culture abroad -YEAR 20I9" DGR nr. 533 of 30 April 20 19. Leader of the project: University of Pavia - Department of Civil Engineering and Architecture, DAda LAB Experimental Research Laboratory, Prof. Sandro Parrinello. Partners: University of Verona - Department of Culture and Civilization, Prof. Arnaldo Soldani; University of Bergamo - School of Engineering, Prof. Alessio Cardaci; University of Florence - DIDA - Department of Architecture, Prof. Stefano Bertocci; University of Montenegro - Faculty of Architecture, Prof. Ilia Lalosevic; Municipality of Verona.

[2] Sandro Parrinello "Introduction" and "An exhibition for the narration of the fortified system of Dalmatia and Montenegro" and Silvia La Placa are responsible for the paragraphs "Prompt relief for the production of a reliable database" and "From databases to drawings and models of fortresses". All images of the contribution are the property of the authors.

[3] The transnational serial site "The Venetian defense works between the 16th and 17th centuries: State from Earth - State from Western Sea" consists of six structures located in Italy, Croatia and Montenegro and extends for over I000 km between Lombardy and eastern Adriatic coast. These large and innovative defensive networks established by the Republic of Venice have an exceptional historical, architectural and technological value and contribute to the configuration of the landscape, strengthening the quality of the visual field of the six structures, as well as the urban and defensive structures dating back to previous historical periods (medieval) and more recent (such as changes and additions from the Napoleonic and Ottoman periods). The defense works in Bergamo, Palmanova and Peschiera del Garda for Italy, Zadar and Sibenik for Croatia, Kotor for Montenegro are part of the UNESCO site. See: <http://mww.unesco.it/it/PatrimonioM Mondiale/Detail/480>. The activities proposed in the project have among the objectives of providing the UNESCO site with a more complete vision of the Venetian works scattered throughout the Mediterranean.

[4]The survey campaign, coordinated by Prof. Sandro Parrinello, was conducted by Dr. Francesca Picchio, PhD. Student Anna Dell'Amico, PhD Student Silvia La Placa, Msc. Stud. Chiara Malusardi, Dante Certomà and Alberto Pettineo students. At the same time, a photographic campaign was created aimed at defining the most peculiar and representative aspects of the heritage, curated by Prof. Marco Morandotti.

[5] Photogrammetric models obtained through Close Range acquisition campaigns conducted both from the ground with reflex cameras set manually and through DJI drones. Laser scanner acquisitions made with two instruments: FARO CAM2 FOCUS SI 50 Laser Scanner and Kaarta Mobile Laser Stencil.Video recording systems through video cameras and $360^{\circ}$ photo cameras.

[6] Field activities lasted 16 hours, 237 scans, to cover the entire urban center and 2 hours, 64 scans, to reach and detect the San Giovanni fort.

[7] For point clouds acquired with TLS technology, the registration took place using CAM2 SCENE software, while the data from the MLS system was managed through the Cloud Compare and Cyclone software.

[8]The Santa Croce laser survey, made for the entire exterior and for all accessible internal environments, was carried out with the FARO CAM2 FOCUS SI 50 Laser Scanner instrumentation set for color restitution. The recording was made on SCENE software, reporting an error of less than $1 \mathrm{~cm}$.

[9] At the end of the conference, held on November 21, 2019, the exhibition was inaugurated, which remained open until November 30, 2019 . For further information see: <http://dadalab.unipv.it/le-fortificazioni-venete-nel-bacino-del-mediterraneoorientale-porta-vescovo-verona-2 I-30-I I-20 I9/.ith> a more complete vision of the Venetian works scattered throughout the Mediterranean 


\section{References}

Arbel Benjamin (1996). Colonie d'oltremare. In Menniti Ippolito Antonio, Benzoni Gino (a cura di). Storia di Venezia. Dalle origini alla caduta della Serenissima, V, II Rinascimento. Roma: Istituto della Enciclopedia italiana, vol. 5, pp. 947-985.

Arbel Benjamin (2013). Venice's maritime Empire in the early modern period. In Eric R. Dursteler (a cura di). A Companion to venetian history, 1400- 1 797. Leiden: Brill's Companions to European History, pp. I25-254.

Gherado Ortalli, Oliver Jens Schmitt (a cura di). (2009). Balcani Occidentali, Adriatico e Venezia fra XIII e XVIII secolo/ Der Westliche Balkan, Der Adriaraum Und Venedig $13^{\text {th }}-18^{\text {th }}$. Jahrhundert. Venezia-Vienna: Austrian Academy of Sciences.

Hocquet Jean Claude (1989). Fiscalité et pouvoir colonial.Venise et le sel Dalmate aux XV et XVI siècles. In Balard Michel (ed.) État et colonisation au Moyen Âge. Lyon: La Manufacture, pp. 277-3। 6.

Krekić Bariša (1995). Venezia e l'Adriatico. In Arnaldi Girolamo, Cracco Giorgio, Tenenti Alberto (a cura di). Storia di Venezia. Dalle origini alla caduta della Serenissima, III, La formazione dello stato patrizio. Roma: Istituto della Enciclopedia italiana, vol. 3 , pp. 5 | -85 .

Paladini Filippo Maria (2002). Un caos che spaventa. Poteri, territori e religioni di frontiera nella Dalmazia della tarda età veneta. Venezia: Marsilio Editore.

Praga Giuseppe (|98I). Storia di Dalmazia. Milano: Dall'Oglio.

Parrinello Sandro, Picchio Francesca (a cura di). (2019). Dalmazia e Montenegro. Le fortificazioni Venete nel Bacino del Mediterraneo Orientale. Procedure per la conoscenza e la Documentazione Digitale del Patrimonio Storico Fortificato. Pavia: Pavia University Press.

\section{Authors}

Sandro Parrinello, Università degli Studi di Pavia, sandro.parrinello@unipv.it

Silvia La Placa, Università degli Studi di Pavia, silvia.laplaca@unipv.it

To cite this chapter. Parrinello Sandro, La Placa Silvia (2020). Ricostruire la memoria dello Stato da Mar attraverso un percorso di conoscenza documentazione e disegno/Rebuilding the Memory of the State da Mar through a path of knowledge, documentation and drawing. In Arena A., Arena M., Brandolino R.G., Colistra D., Ginex G., Mediati D., Nucifora S., Raffa P. (a cura di). Connettere. Un disegno per annodare e tessere. Att del $42^{\circ}$ Convegno Internazionale dei Docenti delle Discipline della Rappresentazione/Connecting. Drawing for weaving relationships. Proceedings of the 42th International Conference of Representation Disciplines Teachers. Milano: FrancoAngeli, pp. 2533-2550. 